\title{
Internationalization Paths of Chinese Local Colleges and Universities -A Case Study of Yanbian University
}

\author{
Jin Yongcan \\ Department of International Exchange and Cooperation, Yanbian University, Yanji China
}

\begin{abstract}
Keywords: local colleges and universities internationalization exchange development suggestion Abstract. Globalization has boosted exchanges in various fields. As an integral part of international exchanges, communication between colleges and universities among various countries has become expansive and profound. As progress continues to be made in China's educational undertakings, colleges and universities in China have also been internationalizing comprehensively, but they still lag behind the highly internationalized ones regarding the internationalization level. Therefore, it is a top priority for China to promote the internationalization process of the Chinese colleges and universities. This paper is an attempt to throw light on the internationalization development of the Chinese local higher learning institutes, and puts forward some suggestions for it.
\end{abstract}

\section{Introduction}

With the rapid development and constant improvement of globalization, Chinese colleges and universities have also experienced fast development. Since 1980s, universities have been internationalizing, first in European and North American countries and then in the developing countries, forming a new wave of university globalization. University globalization has reached countries and universities, gradually becoming a development trend of the higher learning institutes in the future.

\section{Analysis of the Environment for Internationalization of the Local Colleges and Universities}

University globalization concerns the need to take a global perspective in education, learn from the rapidly developed countries the educational ideas and modes, and constantly improve our own educational system. University globalization also serves as a common educational activity, and some European and North American countries adopt it as a way of sending students abroad or an academic exchange activity between the scholars. University internationalization mainly covers five factors. First, adopting internationalized educational ideas, namely cultivating all-round talents with international awareness; second, offering internationalized educational content, mainly referring to opening internationalization-orientated professional courses or adding some internationalization-orientated content in the existing courses; third, conducting academic exchanges and carrying out exchange programs among teachers and students; fourth, conducting international communications and cooperative programs; fifth, offering more educational facilities and establishing new educational systems to realize real-time sharing of the internationalized resources. At present, investigation and study from the case study of a Chinese university shows that the major issues regarding university globalization in China are as follows: first, thanks to the shortage of internationalized faculty resources, educational equipment and financial support, the less internationalized areas only have a few opportunities to engage in small-scale academic exchanges in a single form with the outside world. Therefore, most teachers lack understandings towards the process of internationalization, and have little knowledge about the internationalized professional courses, hence adopting a single and laggard teaching method and philosophy; second, lack of internationalized teaching environment. As the process of internationalization speeds up, some colleges and universities advocate international education blindly with no consideration to the inner needs of the students, thus stirring the psychological inversion of the students. This to some extent prevents the process of university internationalization; third, students hold a unilateral perspective towards university internationalization. The students are devoid of an interest in internationalization, 
only preoccupied with exams, scholarships and grades rankings, failing to involve themself in the landscape of internationalization. Besides, due to a lack of understanding of the professional disciplines, the students are deprived of international competitive awareness and ideas. As a result, the internationalization process of higher learning institutes fails to take on a smooth look of development. Fortunately, various colleges and universities are also exploring in the road of university internationalization, and they are taking reasonable teaching philosophies and measures to speed up internationalization.

\section{Opportunities and Challenges of Internationalization Development of Chinese Local Colleges and Universities}

(1) Opportunities of University Internationalization. First, university internationalization is beneficial for the optimization of the educational resources of the colleges and universities. University globalization enables the colleges and universities to participate in the education cause of the other countries. With the international educational resources, the colleges and universities are able to enrich their own cultural and educational resources through exchanges and communications, thus meeting the need of their own development. The optimization of the educational resources is mainly reflected on the improvement of human resources, organization resources, and material resources. Human resources mainly refer to those engaged in the teaching or study activities, such as the managerial staffs, teachers and students. Organization resources refer to the existing educational model and structure of the colleges and universities. Material resources refer to the hardware facilities of the schools, and philosophy resources are the fundamental resources for the development of the school, including the educational ideas and teaching mentality of the school. In the course of internationalization, the colleges and universities can draw on the educational experience from other countries and bring in the first-class teaching resources to improve their own educational and teaching levels.

Second, university globalization promotes exchanges between the domestic and foreign educational markets. As the Chinese society and economy continue to develop, China is playing an increasing role in the international stage. The traditional Chinese disciplines and preponderant disciplines are attractive to the foreign countries. Therefore, as the cultural communication deepens, a growing number of foreign students and experts are coming to the Chinese learning institutes or organize some activities to research the excellent Chinese culture. This has brought about some educational resources for China. Strengthening cultural exchanges with the foreign countries is beneficial for the development of the cultural education of China.

Third, university globalization helps the establishment of life-long education system. Since its accession to WTO, China has seen great changes concerning its outside economic environment. In order to improve their educational development, the Chinese colleges and universities are supposed to improve their current educational system, and satisfy the students' need of diversified education while meeting the need of the development of the educational market, thus helping the students to develop the idea of life-long education, and boosting the establishment of life-long system.

(2) Challenges Faced by University Globalization.Thanks to internationalization, some problems concerning the foreign affairs management of the Chinese local colleges and universities have been settled and the management range has been expanded. The foreign affairs management work has to some extent promoted the scientific research education and enhanced the construction of the teaching faculty of the higher learning institutes. However, the international construction of the foreign affairs management of the local colleges and universities in China is still at the preliminary stage. Hindered by the traditional management philosophy and mode, the foreign affairs management work is still faced with a series of problems including the weak management basis and the lack of financial support, more or less being contradictory to the development of the local colleges and universities themselves.

First, international awareness is absent in the foreign affairs management work. Under the background of university globalization, the foreign affairs work of the Chinese higher learning 
institutes has been involved in various aspects including cooperative education management, teachers study abroad management, exchange students management and scientific research cooperation management. However, the basic educational model of the Chinese local colleges and universities has not yet been adjusted. The major objective of them remains fostering talents for the local economic development. Therefore, opening-oriented school-running concept is not widely accepted in the local learning institutes, and both the teachers and students have little idea of the international educational concept. Besides, the senior leaders also lack the perspective of international education and the ability to implement it. In a word, they fail to realize the importance of international relationships in higher learning institutions, thus hindering the internationalization of the university foreign affairs management work.

Second, the university foreign affairs management system has yet to be improved. Currently, the foreign affairs management work in the Chinese local colleges and universities is mainly arranged by the Foreign Affairs Office of the school, devoid of related departments for coordination, and supervisory authorities for supervision, resulting in the indiscipline of the university foreign affairs management work. Besides, numerous Chinese local learning institutes misunderstand the university foreign affairs management work, and they think it in the charge of the Foreign Affairs Office of the school, so they only contact with the Office when necessary, giving no consideration to the development and progress of the Office. However, other departments are the pillar for scientific research work of the school, and it's hard for the colleges and universities to make tremendous achievements in the international educational exchanges if the scientific research management is disjointed from the foreign affairs management work. Therefore, the local colleges and universities are supposed to attach great importance to the establishment of the foreign affairs management system, improve the basic management model, and gradually enhance the management level.

Third, the management procession construction has yet to be perfected. An excellent management team is needed in the scientific foreign affairs management, and the professional quality is directly related to the effect and scientific development of the foreign affairs management work. However, there is a lack of foreign affairs work-related talents, and the quality of the related staff has yet to be enhanced. Foreign affairs management work becomes a mere formality in some colleges and universities due to the lack of specialists of foreign affairs. Some schools are equipped with foreign affairs management body and management staff, but the lack of talents and the weakness in the staff's professional knowledge has resulted in the imperfection of the foreign affairs management work, failing to conduct innovative work. Worse still, some newly founded colleges and universities fail to build the independent foreign affairs department due to the shortage of related talents, thus greatly impeding the foreign affairs work. All this has extremely stopped the internationalization of the university foreign affairs management work.

\section{Internationalization Paths of the Chinese Local Colleges and Universities}

First, fostering university globalization concept, and creating foreign affairs environment. University globalization plays an important role in the international relations of China, and the realization of it must be supported by foreign affairs-related activities. Efficient foreign affairs activities enable people to have a better idea of the world, broaden their horizons, promote cross-cultural communication, bring in the globally advanced science and technology, learn from other countries the first-class educational ideas and management methods, cultivate international talents, and improve the scientific research ability and comprehensive strength of the universities. Indeed, specific measures should be taken for fostering university globalization concept. During the practical work, the local colleges and universities can take the following measures to strengthen the idea of international education of the teachers and students. First, the overall English level of the teachers and students should be strengthened because it is one of the basic qualities concerning foreign affairs ability. Targeted training should be adopted for the teachers and students, which can start from simple oral English training, thus making the teachers and students speak English so as to help them build the confidence in the participation of foreign affairs activity. Second, evaluation and 
supervision should become part of the routine work of the senior leaders of the colleges and universities. Only in this way, other departments can extensively participate in the foreign affairs work, thus forming scale effect. Besides, the publicity materials such as the billboard, the brochure and the brief introduction of the college including the teaching situation and scientific research situation of the college should be made both in Chinese and English. On the one hand, it provides convenience for the foreign people. On the other hand, it fortifies the international education of the teachers and students. What's more, exhibitions regarding the foreign affairs work process and achievement can be held to encourage more teachers and students to pay attention to and involve in the foreign affairs activities.

Second, an undergraduate course system featuring multiple coexistence and interaction should be established, thus enhancing cultural inheritance ability. With the multicultural educational resources and characteristic curriculum group as well as rich multicultural teaching faculty, multicultural undergraduate course system is to be built. This system is featured by liberal education, professional education, practical teaching, and extracurricular training, with national, regional and multicultural characteristics. This is aiming to enable the students from different cultural backgrounds to unleash their full potential in academy, society and work. First, the curriculum group with Chinese characteristics should be established based on the national cultural resource. Korean, Korean Culture, Korean Dance, Korean Folk Custom, Korean History and Korean Medicine can constitute a curriculum group. Setting up these courses makes the students obtain the basic knowledge and skill of the national culture, and enables them realize and master the national culture, realizing the integration and innovation of the national culture and the mainstream culture. Second, the curriculum group with regional characteristics should be established. For example, Tourism Resource Exploitation of Yanbian, Introduction of Yanbian Economy, Regional Economics and Law on Regional Ethnic Autonomy can constitute a curriculum group. Offering these courses enable the students to have a better understanding of the economic and social development of the various regions of the nation. Third, importance should be attached to international exchange and cooperation. The curriculum group with regional characteristics should be offered. Typical of the courses are Comparison of Chinese, Korean and Japanese Cultures and Languages, International Economic Cooperation of the Northeast Asia, Korean__DPRK Economies, Korean Law, and Japanese Economy. This can enrich the cultural elements in the students' growth. Fourth, lectures delivered by famous experts from home and abroad should be held, so as to enrich the teaching content.

Third, promoting cultural construction of the colleges and universities, and enhancing the soft sower. Importance should be attached to the publicity of the history of the university so as to promote the cultural and ideological progress and strengthen unity between and progress of various ethnic groups, thus realizing the cohesion of cultural spirit of the colleges and universities. Strategies of excellent campus culture should be implemented, and such theme activities as "Touching the Campus" and "The Most Beautiful Yanbianese" should be carried out. Efforts should be made to foster excellent campus cultural activities which embody the values of the teachers and students. Intensified efforts should be made to strengthen the academic construction and promote the establishment of academic ethics system. More attention should be paid to the improvement of teaching spirit. Teachers with great professional ethics should be set as examples to encourage the teachers to develop advanced educational ideas, foster noble virtues, and cultivate better professional teaching skills. Construction of learning spirit should be included in classroom teaching, extracurricular activities, examinations, and social practice activities. Emphasis should be placed on the development of good psychological quality and good characters of the students including dignity, self-love, self-discipline and independence. Work style construction of the institutes and service departments should be strengthened, holistic awareness, responsibility awareness and service awareness should be fortified, and management efficiency and service level should be improved. It's necessary to realize the benign interaction among the teaching spirit, learning spirit and attitude constructions, thus creating a harmonious environment featuring excellent teaching spirit, good learning spirit and cautious attitudes. 
Fourth, a teaching faculty with multi-cultural background and multilingual advantage should be constructed and fostered. To ensure the teaching quality of multicultural course and the smooth operation of the multi-cultural course system, the teaching faculty with multi-culture should be positively constructed. The stimulus policies should be adopted and improved. For example, the teachers in charge of multi-cultural courses can have an advantage in terms of various awards; encouraging the excellent teachers for the specialized courses, especially the nationally and provincially excellent ones to involve in the multicultural course teaching; sending excellent teachers to study or inspect at the renowned foreign universities. All these can lay a solid foundation for the development of multicultural education.

Fifth, deepening educational reform, and vigorously promoting the quality of talents cultivation. Top priority should be given to the talents cultivation. Construction of first-class discipline should be emphasized, and educational reform should be deepened. Top-notch innovative personnel's training mode should be improved, and greater efforts should be made to improve the establishment of personnel training mode innovative experimental area, national experimental teaching demonstrating center, and distinguished talent training program. Practical teaching should be strengthened, innovation-oriented courses should be offered and innovation and entrepreneurship training should be fortified. More efforts should be made to promote the integration of the professional education and innovation and entrepreneurship education, and universities are supposed to cooperate with scientific research institutions and enterprises to foster talents. "The Project of Innovation in Graduate Education" program should be implemented, and the scientific research and practical innovation abilities should be improved. By so doing, the talent cultivation of the school has been improved, the top-notch innovative personnel's training mode has been perfected, and the talent cultivation quality has been advanced remarkably.

Sixth, colorful campus cultural activities have been carried out in order to create a good multicultural environment. The university cultural construction has been promoted, and the spirit of Yanbian University and good school spirit has been carried forward and inherited. College internet culture construction platform has been established. Activities regarding the school spirit construction year and school anniversary activity month have been conducted. Interview with the theme of "My Yanbian University Dream" has been carried out. The advanced individual, virtue pacesetter and excellent teacher have been selected according to "Three Aspects of Education". Campus cultural activities and social practice activities including the weekend academic lectures, famous scholar lectures, alumnus cultural festival, club cultural festival and psychological cultural month have been be held. By so doing, the campus cultural grade has been improved, creating a good atmosphere of traditional culture.

\section{Conclusion}

Under the influence of internationalization, foreign affairs management work has played an important role in the improvement of the quality of the foreign affairs work and the internationalization of universities. With this into consideration, the Chinese local colleges and universities are supposed to place emphasis on the management of foreign affairs work, and make greater efforts to strengthen the international exchanges and cooperation to make the talent cultivation better meet the requirement of economic globalization.

\section{References}

[1]Students Service and Engagement by Kyle Baillie, Director of Student Service, UFV.

[2] Li Dequan. Providing First-class Education-Analysis of the Satisfaction Evaluation Mechanism focused on "Guests"[J]. Contemporary Youth Research,2005, (8).

[3]Ma Hong. A New Exploration of the Positioning of Foreign Affairs Management at a Local University[J]. Public Administration and Law,2013(4). 
[4]Ding Kun. Thinking on the Foreign Affairs Management of the Newly Founded Higher Institutes[J]. China Adult Education,2013(18).

[5]Hou Yuxia. Suggestions for the Independent Colleges under the Background of University globalization[J]. Thinking,2011 (z2).

[6]Wang Manli. Administration of Foreign Affairs at Universities during the Internationalization of Higher Education[J]. Chinese Geological Education,2005 (3).

[7] Gao Yurong. Research on the Foreign Affairs Management Work under the Background University Globalization[J]. Heilongjiang Researches on Higher Education, 2011 (2).

[8] Chen Qiang, Huo Jiazhen. Quality and Beneficial Outlooks on International Graduates Cultivation[J]. Academic Degrees \& Graduate Education, 2005 (7): 21-25.

[9] Qin Jie, Zhong Fanng, Cai Jianying. Practice and Discussion of Student-Exchange Project in Universities.[J]. Science and Technology Innovation Herald, 2011（32） : 194-195.

[10] Ming Xiaofeng, Qi Xiaofeng. An Analysis on the Tactics for the Internationalization of Local Universities in China[J]. Journal of Nantong University (Education Science Edition),2007, (4). 